\title{
Problematika Penguasaan Tiga Bahasa pada Santri Putra Kelas X di Pondok Pesantren Modern Zam-Zam Muhammadiyah Cilongok Tahun Ajaran 2019/2020
}

\author{
Problems on Three Languages Mastery on Male $10^{\text {th }}$ Graders of Zam-Zam Muhammadiyah \\ Modern Islamic Boarding School Cilongok Academic Year 2019/2020 \\ ${ }^{1 *}$ Nanang Rahmat Hidayat, ${ }^{2}$ Santhy Hawanti \\ ${ }^{1,2)}$ Universitas Muhammadiyah Purwokerto \\ *email: nanangra4@gmail.com, santhyhawanti.ump@gmail.com
}

\begin{abstract}
Diajukan: 05/09/2020

Diterima: 09/07/2021

Diterbitkan: $13 / 07 / 2021$
\end{abstract}

Histori Artikel:

\begin{abstract}
ABSTRAK
Penelitian ini berjudul "Problematika Penguasaan Tiga Bahasa Pada Santri Putra Kelas X di Pondok Pesantren Modern Zam Zam Muhammadiyah Cilongok Tahun Ajaran 2019/2020”. Tujuan dari penelitian ini adalah untuk mengidentifikasi (1) problematika penguasaan bahasa Arab, bahasa Inggris, dan bahasa Indonesia dari segi linguistik dan nonlinguistik pada santri putra kelas $X$ di Pondok Pesantren Modern Zam-zam Muhammadiyah Cilongok, (2) faktor apa saja yang menyebabkan problematika penguasaan bahasa bahasa Arab, bahasa Inggris, dan bahasa Indonesia dari segi linguistik dan nonlinguistik pada santri putra kelas X di Pondok Pesantren Modern Zam-Zam Muhammadiyah Cilongok. Penelitian ini dilaksanakan di Pondok Pesantren Modern Zam Zam Muhammadiyah Cilongok, Banyumas. Instrumen yang digunakan dalam penelitian ini berupa instrumen angket dan wawancara. Teknik analisis data dalam penelitian ini menggunakan analisis data kualitatif deskriptif. Hasil penelitian tentang problematika penguasaan bahasa Arab menyatakan adanya permasalahan pada aspek fonologi, morfologi, semantik, sintaksis, aspek kemampuan individu siswa, aspek keterba-tasan jam belajar, dan aspek guru dan metode pengajaran. Hasil penelitian tentang problematika penguasaan bahasa Inggris menyatakan adanya permasalahan pada aspek fonologi, morfologi, semantik, sintaksis, aspek kemampuan individu siswa, aspek guru dan metode pembelajaran, dan aspek lingkungan/sosial. Sedangkan hasil penelitian tentang problematika penguasaan bahasa Indonesia menyatakan adanya permasalahan pada aspek fonologi, sintaksis, dan sarana/prasarana.
\end{abstract}

Kata kunci: Problematika; Penguasaan; Tiga Bahasa

\begin{abstract}
This research is entitled "The Problems of Mastery of Three Languages of Male Santri in Class X at the Modern Zam-Zam Muhammadiyah Islamic Boarding School, Cilongok, Academic Year 2019/2020". The purpose of this study was to identify: (1) linguistic and nonlinguistic mastery of Arabic, English, and Indonesian language problems in male santri of class X at the Modern Zam-Zam Islamic Boarding School Muhammadiyah Cilongok, and (2) the factors that cause linguistic and nonlinguistic mastery of Arabic, English and Indonesian language problems in male santri of class X at the Zam-Zam Muhammadiyah Islamic Boarding School Cilongok. This research was conducted at the Modern Zam-Zam Muhammadiyah Islamic Boarding School Cilongok, Banyumas. The instruments used in this research were questionnaire and interview. The data analysis technique used in this study is descriptive qualitative data analysis. The results of research revealed that there were problems in the aspects of phonology, morphology, semantics, syntax, aspects of individual student abilities, aspects of limited learning hours, and aspects of teachers and learning methods. Meanwhile, the problems of
\end{abstract}


Nanang Rahmat Hidayat, Santhy Hawanti

Problematika Penguasaan Tiga Bahasa pada Santri Putra Kelas X di Pondok Pesantren Modern Zam-Zam

Muhammadiyah Cilongok Tahun Ajaran 2019/2020

mastery of English phonology, morphology, semantics, syntax, aspects of individual student abilities, aspects of teachers and learning methods, and environmental/ social aspects. Finally, the problems of mastery the Indonesian language phonology, syntax, and facilities/infrastructure.

Keywords: Problematics; Mastery; Three Languages

\section{PENDAHULUAN}

Kaum behavioristik atau kaum empiris mengatakan bahwa manusia lahir seperti kertas kosong. Anak yang lahir dianggap kosong dari bahasa, sehingga tidak ada unsur atau struktur linguistik yang dibawa. Artinya kemampuan dan keterampilan bahasa didapat melalui proses belajar. Struktur linguistik tersebut akan berkembang melalui proses belajar dan interaksi sosial yang dialami. Proses belajar bahasa itulah yang akan membawa anak kepada pengukuhan terhadap tingkah laku sosialnya. Pateda (1990 : 43)

Dalam menyambut era kiwari, menguasai bahasa pertama saja dirasa kurang cukup dalam persaingan global. Era kiwari tidak bisa dihindarkan oleh siapapun. Cepat atau lambat manusia akan dipaksa menyesuaikan dengan tatanan kehidupan yang semakin maju, dari segi teknologi sampai ekonomi yang sudah didigitalisasi.

Bahasa menjadi salah satu kunci dalam memasuki era kiwari. Penguasaan bahasa internasional atau bahasa asing memberi jalan komunikasi lebih luas, sehingga seseorang bisa mengakses ilmu pengetahuan dan teknologi yang jauh lebih banyak sebagai bekal mengarungi kehidupan global.

Salah satu kurikulum di asrama, yaitu dengan pengajaran bahasa asing yang memang sudah menjadi ciri khusus bagi pesantren modern. Santri mempelajari tiga bahasa, yaitu bahasa Indonesia sebagai bahasa nasional dan bahasa persatuan, bahasa Arab yang merupakan bahasa Al-Quran, agar santri mampu mengikuti mata pelajaran kepondokan dengan baik, dan bahasa Inggris yang merupakan bahasa internasinal, agar santri dapat mengepakkan sayapnya kemana saja yang mereka inginkan setelah lulus.

Pondok Pesantren (Ponpes) Modern Zam-Zam Muhammadiyah Cilongok merupakan salah satu pondok pesantren modern yang didirikan untuk menajawab kebutuhan masyarakat akan pendidikan yang berbasis agama namun dengan mengembangkan pembelajaran yang modern dan mengikuti dinamika perkembangan global. Implementasi pembelajaran bahasa di Ponpes Zam-Zam dilaksanakan pada dua waktu, yaitu jam pembelajaran formal pada pagi hari dan informal pada malam hari. Pembelajaran bahasa Indonesia, bahasa Arab, dan bahasa Inggris patutnya sekolah reguler pada umumnya dilaksanakan pada pagi hari dengan waktu pertemuan selama 4 jam pelajaran yang dikendalikan oleh Waka Kurikulum kedinasan SMA. Selanjutnya khusus untuk bahasa Arab dan bahasa Inggris dilaksanakan pula pada malam hari yang dikendalikan oleh Qismu Al Lughoh atau bagian bahasa yang memiliki program kebahasaan.

Dalam proses penguasaan ketiga bahasa tersebut tentu santri banyak mengalami kendala, baik kendala linguistik maupun kendala non linguistik. Terlebih ada beberapa santri putri yang berasal dari Arab Saudi. Berangkat dari permasalahan tersebut, maka peneliti tertarik untuk mempelajari dan meneliti problematika penguasaan tiga bahasa pada santri putra kelas X di Pondok Pesantren Modern Zam-Zam Muhammadiyah Cilongok.

Berdasarkan rumusan masalah yang telah ditetapkan, maka tujuan penelitian ini adalah untuk mengidentifikasi problematika penguasaan bahasa bahasa Arab, bahasa Inggris, dan bahasa Indonesia dari segi linguistik dan nonlinguistic, serta untuk mengetahui faktor apa saja yang menyebabkan problematika penguasaan bahasa bahasa Arab, bahasa Inggris, dan bahasa Indonesia dari segi linguistik dan nonlinguistik.

\section{METODE}

Metode yang digunakan dalam penelitian ini yaitu metode penelitian deskriptif kualitatif. Metode penelitian ini dipilih karena penelitian ini dilakukan dalam kondisi yang 
alamiah, dan analisis data yang terkumpul lebih bersifat kualitatif. Dengan demikian sesuai dengan tujuan dari penelitian ini, maka metode penelitian kualitatif diterapkan untuk menjawab rumusan masalah.

Penelitian telah dilaksanakan di Ponpes Modern Zam-Zam Muhammadiyah Cilongok yang beralamatkan di Jl. Masjid Baitul Matien, komplek Perguruan Muhammadiyah di Desa Pernasidi, Kecamatan Cilongok, Kabupaten Banyumas, dengan data dalam penelitian ini yaitu problematika penguasaan berbahasa santri, baik bahasa lisan mau pun bahasa tulis. Analisis data dilakukan terhadap data yang telah direduksi, baik data problematika linguistik dan problematika nonlinguistik. Analisis data diambil dari data angket yang dianalisis dengan menghitung persentase penguasaan bahasa santri, kemudian dideskripsikan secara kualitatif, dan dari data wawancara.

\section{HASIL DAN PEMBAHASAN}

\section{Problematika yang Dihadapi Santri Dalam Penguasaan Bahasa Arab}

a. Problematika Linguistik

\section{1) Aspek Fonologi (Tata Bunyi)}

Seluruh santri sudah menghafal seluruh huruf hijaiyah. Selanjutnya dalam membaca harakat tanwin hampir seluruh santri sudah menguasainya. Kemudian masih banyak santri yang mengalami kesulitan dalam membedakan bunyi huruf yang relatif mirip. Berdasarkan hasil angket dapat diidentifikasi bahwa kesulitan yang dihadapi oleh santri disebabkan karena masih sulitnya santri mengetahui tempat keluarnya bunyi huruf hijaiyah. Serta ada beberapa huruf yang tempat keluarnya tergolong sulit untuk dilafalkan. Sehingga salah meletakan lidah saja dapat memengaruhi keluarnya bunyi huruf hijaiyah.

\section{2) Aspek Morfologi (Pembentukan Kata)}

Sudah banyak santri yang telah mengetahui tentang ilmu shorof. Namun banyak juga santri yang mengalami kendala berupa menghafal perubahan kata bahasa Arab. Selain itu problematika dalam belajar kaidah ilmu shorof cukup banhyak. Sedangkan untuk yang merasa kesulitan dalam menghafal fi'il dengan isim hampir seluruh santri. Berdasarkan hasil angket dapat diidentifikasi bahwa kesulitan yang dihadapi oleh santri kemungkinan disebabkan karena masih sulitnya santri dalam menghafal jenis-jenis perubahan kata, karena dalam bahasa Arab sekadar memanjangkan harakat saja makna sudah berbeda. Selain itu santri juga masih kesulitan dalam mempelajari kaidah ilmu shorof.

\section{3) Aspek Sintaksis (Pembentukan Kalimat)}

Santri yang sudah tahu tentang ilmu nahwu hampir menyeluruh. Namun masih terdapat cukup banyak santri mengalami kesulitan dalam membuat kalimat sesuai kaidah ilmu nahwu dan kesulitan dalam belajar ilmu nahwu. Berdasarkan hasil tersebut dapat diidentifikasi bahwa kesulitan yang dihadapi oleh santri disebabkan karena masih sulitnya santri dalam mendalami kaidah ilmu nahwu, sehingga dalam membuat kalimat masih mengalami kesulitan. Santri juga masih belum mendapatkan banyak perbendaharaan kata yang dapat menjadi modal utama dalam membuat kalimat.

\section{4) Aspek Semantik (Pemaknaan)}

Santri yang masih mengalami kesulitan dalam menerjemahkan bahasa arab ke bahasa Indonesia. Sedangkan santri yang masih mengalami kesulitan untuk menemukan makna kata bahasa Arab dalam kamus masih cukup banyak.

Berdasarkan hasil angket dapat diidentifikasi bahwa kesulitan yang dihadapi oleh santri kemungkinan disebabkan karena masih sulitnya santri dalam mengartikan makna kata dari bahasa Arab ke bahasa Indonesia. 
Nanang Rahmat Hidayat, Santhy Hawanti

Problematika Penguasaan Tiga Bahasa pada Santri Putra Kelas X di Pondok Pesantren Modern Zam-Zam Muhammadiyah Cilongok Tahun Ajaran 2019/2020

b. Problematika Non-linguistik

1) Aspek Kemampuan Individu Siswa

Tabel 4.1: Data Konversi Angket Aspek Kemampuan Individu Siswa

\begin{tabular}{|c|c|c|c|c|}
\hline \multirow{2}{*}{ Point } & \multirow{2}{*}{ Resp. } & \multicolumn{2}{|c|}{ Kelas X } & \multirow{2}{*}{ Pelisih } \\
\cline { 3 - 4 } & & $\sqrt{\%}$ & $\mathbf{X}$ & \\
\cline { 3 - 4 } & & $60,3 \%$ & $39,7 \%$ & $20,6 \%$ \\
\hline A & 14 & $79,5 \%$ & $20,5 \%$ & $54,5 \% \%$ \\
\hline B & 14 & $72,6 \%$ & $27,4 \%$ & $45,2 \%$ \\
\hline C & 14 & $212,4 \%$ & $87,6 \%$ & $120,3 \%$ \\
\hline \multicolumn{2}{|c|}{ Jumlah } & &
\end{tabular}

Kesulitan pada aspek siswa ini, yaitu pertama sebanyak $60,3 \%$ masih belum memperoleh perbendaharaan kata bahasa Arab yang banyak. Kedua, sejumlah 20,5\% masih belum mendapatkan motivasi dari orangtua. Ketiga, sejumlah 27,4\% masih belum termotivasi oleh guru dalam belajar bahasa Arab. Berdasarkan hasil angket dapat diidentifikasi bahwa kesulitan yang dihadapi oleh diri santri kemungkinan disebabkan karena masih kurangnya motivasi dari diri santri atau pun dari orangtua dan guru, sehingga santri dalam belajar bahasa Arab masih kurang tekun. Selain itu juga santri masih kurang dalam upaya memperoleh perbendaharaan kosakata bahasa Arab sehingga dapat mempengaruhi dalam berkomunikasi.

\section{2) Aspek Sarana/Prasarana}

Tabel 4.2: Data Konversi Angket Aspek Sarana/prasarana

\begin{tabular}{|l|l|l|l|l|}
\hline \multirow{2}{*}{ Point } & \multirow{2}{*}{ Resp. } & \multicolumn{2}{|c|}{ Kelas X } & \multirow{2}{*}{ Pelisih } \\
\cline { 3 - 4 } & & $\sqrt{*})$ & Xersentase & \\
\cline { 3 - 4 } & & $\sqrt{*})$ & \\
\hline A & 14 & $68,5 \%$ & $31,5 \%$ & $37 \%$ \\
\hline B & 14 & $86,3 \%$ & $13,7 \%$ & $72,6 \%$ \\
\hline Jumlah & $154,8 \%$ & $45,2 \%$ & $109,6 \%$ \\
\hline
\end{tabular}

Sejumlah $68,5 \%$ memiliki buku bacaan berbahasa Arab selain buku pelajaran. Selanjutnya sejumlah $86,3 \%$ sudah memiliki kamus bahasa Arab-Indonesia. Berdasarkan hasil angket dapat diidentifikasi bahwa kesulitan yang dihadapi oleh diri santri disebabkan karena masih kurangnya fasilitas yang disediakan oleh ponpes sebagai upaya peningkatan penguasaan berbahasa santri. Kekurangan tersebut meliputi pengadaan buku di perpustakaan, ruang baca perpustakaan yang kurang lega, serta tidak adanya lab bahasa yang dapat digunakan untuk meningkatkan proses pembelajaran bahasa.

\section{3) Aspek Keterbatasan Jam Belajar}

Tabel 4.3: Data Konversi Angket Aspek Keterbatasan Jam Belajar

\begin{tabular}{|c|c|c|c|c|}
\hline \multirow{3}{*}{ Point } & \multirow{3}{*}{ Resp. } & \multicolumn{2}{|c|}{ Kelas X } & \multirow{3}{*}{ Selisih $(\%)$} \\
\hline & & \multicolumn{2}{|c|}{ Persentase } & \\
\hline & & $\sqrt{ }$ & $\mathbf{X}$ & \\
\hline A & 14 & $52,1 \%$ & $47,9 \%$ & $4,2 \%$ \\
\hline \multicolumn{2}{|c|}{ Jumlah } & $52,1 \%$ & $47,9 \%$ & $4,2 \%$ \\
\hline
\end{tabular}

Sejumlah 52,1\% masih belum memahami materi bahasa Arab hanya dengan 2 jam pelajaran. Berdasarkan hasil angket dapat diidentifikasi bahwa kesulitan yang dihadapi oleh diri santri disebabkan karena masih sulit memahami materi yang disampaikan oleh guru hanya dengan 2 jam pelajaran, serta waktu belajar santri di luar sekolah yang masih kurang dimanfaatkan sebagian besar santri.

4) Aspek Guru dan Metode Pembelajaran

Tabel 4.4: Data Konversi Angket Aspek Guru Dan Metode Pembelajaran

\begin{tabular}{|c|c|c|c|c|}
\hline \multirow{3}{*}{ Point } & \multirow{3}{*}{ Resp. } & \multirow{2}{*}{\multicolumn{2}{|c|}{$\begin{array}{c}\text { Kelas X } \\
\text { Persentase }\end{array}$}} & \multirow{3}{*}{ Selisih (\%) } \\
\hline & & & & \\
\hline & & $\sqrt{ }$ & $\mathbf{X}$ & \\
\hline A & 14 & $50,7 \%$ & $49,3 \%$ & $1,4 \%$ \\
\hline B & 14 & $43,8 \%$ & $56,2 \%$ & $13,6 \%$ \\
\hline $\mathrm{C}$ & 14 & $64,4 \%$ & $35,6 \%$ & $28,8 \%$ \\
\hline \multicolumn{2}{|c|}{ Jumlah } & $158,9 \%$ & $141,1 \%$ & $17,8 \%$ \\
\hline
\end{tabular}


Nanang Rahmat Hidayat, Santhy Hawanti

Problematika Penguasaan Tiga Bahasa pada Santri Putra Kelas X di Pondok Pesantren Modern Zam-Zam

Muhammadiyah Cilongok Tahun Ajaran 2019/2020

Sebanyak 49,3\% merasa bahwa penjelasan guru bahasa Arab belum mudah dipahami. Sebanyak $43,8 \%$ lebih suka membaca materi saja daripada praktik berbicara. Namun terdapat $64,4 \%$ yang menyukai praktik berbicara di depan kelas. Berdasarkan hasil angket dapat diidentifikasi bahwa kesulitan yang dihadapi oleh diri siswa kemungkinan disebabkan karena masih sulitnya siswa memahami penjelasan guru dan belum tingginya motivasi siswa dalam melakukan praktik berbicara di kelas sehingga kemampuan kosakatanya belum berkembangn baik.

\section{5) Aspek Lingkungan/social}

Tabel 4.5: Data Konversi Angket Aspek Lingkungan/sosial

\begin{tabular}{|c|c|c|c|c|}
\hline \multirow{2}{*}{ Point } & \multirow{2}{*}{ Resp. } & \multicolumn{2}{|c|}{ Kelas X } & Selisih (\%) \\
\cline { 3 - 4 } & & $\sqrt{|c|}$ Persentase & \multirow{2}{*}{} \\
\cline { 3 - 4 } & & $\sqrt{ }$ & $\mathbf{X}$ & \\
\hline A & 14 & $56,2 \%$ & $43,8 \%$ & $12,4 \%$ \\
\hline B & 14 & $31,5 \%$ & $68,5 \%$ & $37 \%$ \\
\hline C & 14 & $32,9 \%$ & $67,1 \%$ & $35,8 \%$ \\
\hline \multicolumn{2}{|c|}{ Jumlah } & $120,9 \%$ & $179,4 \%$ & $85,2 \%$ \\
\hline
\end{tabular}

Sebanyak 43,8\% masih merasa takut untuk berbicara menggunakan bahasa Arab dengan guru. Selanjutnya pada point B hanya sebanyak $31,5 \%$ yang sering mengajak teman berbicara menggunakan bahasa Arab. sedangkan santri yang sering menyapa menggunakan bahasa Arab hanya sebanyak $32,9 \%$. Berdasarkan hasil angket dapat diidentifikasi bahwa kesulitan yang dihadapi oleh diri siswa kemungkinan disebabkan karena ketidakberanian santri untuk berbicara menggunakan bahasa Arab dengan guru. Ketakutan tersebut kemungkinan karena kurang banyaknya kosa kata yang dimiliki, serta susunan kalimat santri yang kurang bagus.

\section{Problematika yang Dihadapi Santri Dalam Penguasaan Bahasa Inggris}

a. Problematika Linguistik

1) Aspek Fonologi (Tata Bunyi)
Beberapa santri masih mengalami kesulitan dalam mengucapkan huruf /r/, /s/, /z/ dan /th/. Sedangkan kesulitan dalam membedakan bunyi huruf: /a/, /e/, dan /i/ dalam bahasa Inggris juga masih banyak santri yang belum dapat mengucapkan dengan benar. Selanjutnya masih banyak juga santri yang belum memiliki pengucapan (pronunciation) bahasa Inggris yang baik. Berdasarkan hasil angket dapat diidentifikasi bahwa kesulitan yang dihadapi oleh santri disebabkan karena masih sulitnya santri mengetahui pengucapan huruf dalam bahasa Inggris. Serta ada beberapa huruf yang sama tergolong sulit untuk diucapkan.

\section{2) Aspek Morfologi (Pembentukan kata)}

Ada beberapa santri masih mengalami kesulitan dalam membedakan verb dengan adjective. Sedangkan dalam belajar tata bahasa (tenses) justru banyak santri yang masih mengalami kesulitan. Selanjutnya dalam menghafal regular dan irregular verb hampir seluruh santri masih mengalami kesulitan. Berdasarkan hasil angket dapat diidentifikasi bahwa kesulitan yang dihadapi oleh santri kemungkinan disebabkan karena masih sulitnya santri dalam membedakan jenisjenis kata, serta kesulitan dalam mempelajari tenses dan menghafal regular dan irregular verb.

\section{3) Aspek Sintaksis (Pembentukan Kalimat)} Masih banyak santri mengalami kesulitan dalam belajar kaidah tata bahasa (grammar) bahasa Inggris. Selanjutnya banyak juga santri yang masih mengalami kesulitan dalam membuat kalimat dengan kaidah bahasa Inggris. Berdasarkan hasil angket dapat diidentifikasi bahwa kesulitan yang dihadapi oleh santri disebabkan karena masih sulitnya santri dalam mendalami kaidah tata bahasa (grammar), sehingga dalam membuat kalimat masih mengalami kesulitan. Santri juga masih belum mendapatkan banyak perbendaharaan kata yang dapat menjadi modal utama dalam membuat kalimat.

\section{4) Aspek Semantik (Pemaknaan)}

Hampir seluruh santri masih sulit menerjemahkan bahasa Inggris ke bahasa Indonesia. Selanjutnya terdapat beberapa santri 
Nanang Rahmat Hidayat, Santhy Hawanti

Problematika Penguasaan Tiga Bahasa pada Santri Putra Kelas X di Pondok Pesantren Modern Zam-Zam Muhammadiyah Cilongok Tahun Ajaran 2019/2020

masih sulit menemukan makna kata bahasa Inggris dalam kamus. Berdasarkan hasil angket dapat diidentifikasi bahwa kesulitan yang dihadapi oleh santri kemungkinan disebabkan karena masih sulitnya santri dalam mengartikan makna kata dari bahasa Inggris ke dalam bahasa Indonesia.

b. Problematika Non-linguistik

1) Aspek Kemampuan Individu Siswa

Tabel 5.1: Data Konversi Angket Aspek Kemampuan Individu Siswa

\begin{tabular}{|c|c|c|c|c|}
\hline \multirow{2}{*}{ Point } & \multirow{2}{*}{ Resp. } & \multicolumn{2}{|c|}{ Kelas X } & \multirow{2}{*}{\begin{tabular}{c}
\multirow{2}{*}{ Selisih } \\
\cline { 3 - 4 }
\end{tabular}} \\
\cline { 3 - 4 } & & $\sqrt{\%})$ \\
\hline A & 14 & $80,8 \%$ & $19,2 \%$ & $61,6 \%$ \\
\hline B & 14 & $71,2 \%$ & $28,8 \%$ & $42,4 \%$ \\
\hline C & 14 & $32,9 \%$ & $67,1 \%$ & $34,2 \%$ \\
\hline D & 14 & $51,4 \%$ & $48,6 \%$ & $2,8 \%$ \\
\hline \multicolumn{2}{|c|}{ Jumlah } & $236,3 \%$ & $167,7 \%$ & $141 \%$ \\
\hline
\end{tabular}

Sebanyak 19,2\% masih belum memiliki motivasi ingin pandai berbahasa Inggris. Selanjutnya sebanyak belum banyak $71,2 \%$ belum memperoleh perbendaharaan kosakata bahasa Inggris. Sedangkan sebanyak $67,1 \%$ belum merasa senang membaca buku berbahasa Inggris, serta sebanyak $48,6 \%$ belum termotivasi semangat belajar bahasa Inggris dari guru bahasa Inggris di sekolah. Berdasarkan hasil angket dapat diidentifikasi bahwa kesulitan yang dihadapi oleh diri santri kemungkinan disebabkan karena masih kurangnya motivasi dari diri santri atau pun dari orangtua dan guru, sehingga santri dalam belajar bahasa Inggris masih kurang tekun. Selain itu juga santri masih kurang dalam upaya memperoleh perbendaharaan kosakata bahasa Inggris sehingga dapat mempengaruhi dalam berkomunikasi.
2) Aspek Sarana/prasarana

Tabel 5.2: Data Konversi Angket Aspek Sarana/prasarana

\begin{tabular}{|c|c|c|c|l|}
\hline \multirow{2}{*}{ Point } & \multirow{2}{*}{ Resp. } & \multicolumn{2}{|c|}{ Kelas X } & \multicolumn{2}{l|}{$\begin{array}{l}\text { Selisih } \\
(\%)\end{array}$} \\
\cline { 3 - 4 } & & \multicolumn{2}{|c|}{ Persentase } & \multirow{2}{*}{} \\
\cline { 3 - 4 } & & $\sqrt{ }$ & $\mathbf{X}$ & \\
\hline A & 14 & $82,2 \%$ & $17,8 \%$ & $64,4 \%$ \\
\hline \multicolumn{2}{|c|}{ Jumlah } & $82,2 \%$ & $17,8 \%$ & $64,4 \%$ \\
\hline
\end{tabular}

Sebanyak $17,8 \%$ belum memiliki kamus bahasa Inggris. Berdasarkan hasil angket dapat diidentifikasi bahwa kesulitan yang dihadapi oleh diri santri disebabkan karena masih kurangnya fasilitas yang disediakan oleh ponpes sebagai upaya peningkatan penguasaan berbahasa santri. Kekurangan tersebut meliputi pengadaan buku di perpustakaan, ruang baca perpustakaan yang kurang lega, serta tidak adanya lab bahasa yang dapat digunakan untuk meningkatkan proses pembelajaran bahasa.

\section{3) Aspek Keterbatasan Jam Belajar}

Tabel 5.3: Data Konversi Angket Aspek Keterbatasan Jam Belajar

\begin{tabular}{|c|c|c|c|c|}
\hline \multirow{2}{*}{ Point } & \multirow{2}{*}{ Resp. } & \multicolumn{2}{|c|}{ Kelas X } & \multirow{2}{*}{ Persentase } \\
\cline { 3 - 4 } & & $\sqrt{ }$ & $\mathbf{X}$ & \\
\cline { 3 - 4 } & & $32,9 \%$ & $67,1 \%$ & $35,8 \%$ \\
\hline A & 14 & $32,9 \%$ & $67,1 \%$ & $35,8 \%$ \\
\hline \multicolumn{2}{|c|}{ Jumlah } & &
\end{tabular}

Sebanyak 32,9\% merasa 4 jam pelajaran masih belum paham dengan materi pelajaran yang disampaikan oleh guru bahasa Inggris. Berdasarkan hasil angket dapat diidentifikasi bahwa kesulitan yang dihadapi oleh diri santri disebabkan karena masih sulit memahami materi yang disampaikan oleh guru hanya dengan 4 jam pelajaran, serta waktu belajar santri di luar sekolah yang masih kurang dimanfaatkan sebagian besar santri. 
Nanang Rahmat Hidayat, Santhy Hawanti

Problematika Penguasaan Tiga Bahasa pada Santri Putra Kelas X di Pondok Pesantren Modern Zam-Zam

Muhammadiyah Cilongok Tahun Ajaran 2019/2020

4) Aspek Guru dan Metode Pembelajaran

Tabel 5.4: Data Konversi Angket Aspek Guru dan Metode Pembelajaran

\begin{tabular}{|c|c|c|c|c|}
\hline \multirow{2}{*}{ Point } & \multirow{2}{*}{ Resp. } & \multicolumn{2}{|c|}{ Kelas X } & \multirow{2}{*}{ Selisih } \\
\cline { 3 - 4 } & & $\sqrt{ }$ & $\mathbf{X}$ & \\
\cline { 3 - 4 } & & $71,2 \%$ & $28,8 \%$ & $42,4 \%$ \\
\hline A & 14 & $82,2 \%$ & $17,8 \%$ & $64,4 \%$ \\
\hline B & 14 & $47,9 \%$ & $52,1 \%$ & $4,2 \%$ \\
\hline C & 14 & $38,4 \%$ & $61,6 \%$ & $23,2 \%$ \\
\hline D & 14 & $239,7 \%$ & $160,3 \%$ & $134,2 \%$ \\
\hline \multicolumn{2}{|c|}{ Jumlah } & &
\end{tabular}

Sebanyak $82,2 \%$ mudah memahami bahasa Inggris dengan mendengarkan lagu atau menonton film. Kemudian sabanyak 47,9\% lebih suka membaca materi saja daripada praktek berbicara, serta sebanyak $61,6 \%$ tidak senang dengan praktek berbicara bahasa Inggris di depan kelas. Berdasarkan hasil angket dapat diidentifikasi bahwa kesulitan yang dihadapi oleh diri siswa kemungkinan disebabkan karena masih sulitnya siswa memahami penjelasan guru dan belum tingginya motivasi siswa dalam melakukan praktik berbicara di kelas sehingga kemampuan kosakatanya belum berkembangn baik.

\section{5) Aspek Lingkungan/social}

Tabel 5.5: Data Konversi Angket Aspek Lingkungan/sosial

\begin{tabular}{|c|c|c|c|c|}
\hline \multirow{2}{*}{ Point } & \multirow{2}{*}{ Resp. } & \multicolumn{2}{|c|}{ Kelas X } & \multicolumn{2}{|c|}{$\begin{array}{l}\text { Selisih } \\
(\%)\end{array}$} \\
\cline { 3 - 4 } & & \multicolumn{2}{|c|}{ Persentase } & \multirow{2}{*}{} \\
\cline { 3 - 5 } & & $\sqrt{ }$ & $\mathbf{X}$ & \\
\hline A & 14 & $38,4 \%$ & $61,6 \%$ & $23,2 \%$ \\
\hline B & 14 & $27,4 \%$ & $72,6 \%$ & $45,2 \%$ \\
\hline C & 14 & $17,8 \%$ & $82,2 \%$ & $64,4 \%$ \\
\hline \multicolumn{2}{|c|}{ Jumlah } & $83,6 \%$ & $216,4 \%$ & $132,8 \%$ \\
\hline
\end{tabular}

Sebanyak $61,6 \%$ tidak berani berbicara bahasa Inggris dengan guru. Selanjutnya dalam mengajak teman bertutur menggunakan bahasa Inggris hanya $27,4 \%$ yang sering melakukan. Sedangkan sebanyak $82,2 \%$ jarang menyapa menggunakan bahasa Inggris ketika bertemu guru atau teman di sekolah. Berdasarkan hasil angket dapat diidentifikasi bahwa kesulitan yang dihadapi oleh diri siswa kemungkinan disebabkan karena ketidakberanian santri untuk berbicara menggunakan bahasa Inggris dengan guru. Ketakutan tersebut kemungkinan karena kurang banyaknya kosa kata yang dimiliki, serta susunan kalimat santri yang kurang bagus.

\section{Problematika yang Dihadapi Santri Dalam Penguasaan Bahasa Indonesia}

a. Problematika Linguistik

1) Aspek Fonologi (Tata Bunyi)

Hanya sedikit santri yang masih sulit mengucapkan huruf /r/, /f/, dan /v/. sedangkan santri yang dapat bertutur menggunakan bahasa Indonesia dengan lancer hampir menyeluruh. Berdasarkan hasil angket dapat diidentifikasi bahwa kesulitan yang dihadapi oleh santri disebabkan karena masih sulitnya santri yang berasal dari daerah tertentu dalam mengucapkan beberapa kata yang sulit diucapkan. Sehingga dapat berpengaruh dalam kelancaran berbicara.

\section{2) Aspek Morfologi (Pembentukan kata)}

Beberapa santri belum tahu cara membedakan kata kerja dengan kata sifat. Sedangkan sebanyak beberapa santri masih sulit membedakan kata dasar dengan kata berimbuhan. Berdasarkan hasil angket dapat diidentifikasi bahwa kesulitan yang dihadapi oleh santri kemungkinan disebabkan karena masih sulitnya santri dalam menghafal jenisjenis kata, sehingga dapat berpengaruh terhadap pengetahuannya dalam mengidentifikasi kata dasar dengan kata berimbuhan.

3) Aspek Sintaksis (Pembentukan Kalimat) Beberapa santri masih sulit belajar kaidah bahasa Indonesia. Selanjutnya ditunjukan bahwa banyak santri dapat membuat kalimat yang baik sesuai kaidah/struktur (SPOK) bahasa Indonesia, namun belum dapat mengidentifikasi jabatan kata dalam kalimat. Berdasarkan hasil angket dapat diidentifikasi bahwa kesulitan yang dihadapi oleh santri disebabkan karena masih 
Nanang Rahmat Hidayat, Santhy Hawanti

Problematika Penguasaan Tiga Bahasa pada Santri Putra Kelas X di Pondok Pesantren Modern Zam-Zam Muhammadiyah Cilongok Tahun Ajaran 2019/2020

sulitnya santri dalam mendalami kaidah/susunan kalimat bahasa Indonesia, sehingga dalam membuat kalimat masih mengalami kesulitan.

\section{4) Aspek Semantik (Pemaknaan)}

Beberapa santri masih sulit memahami perubahan makna bahasa Indonesia. Sedangkan beberapa santri belum dapat membedakan makna denotatif dengan makna konotatif. Berdasarkan hasil angket dapat diidentifikasi bahwa kesulitan yang dihadapi oleh santri kemungkinan disebabkan karena masih sulitnya santri dalam membedakan jenis mankna dan mengidentifikasi perubahan makna kata bahasa Indonesia.

b. Problematika Non-linguistik

1) Aspek Kemampuan Individu Siswa

Tabel 6.1: Data Konversi Angket Aspek Kemampuan Individu Siswa

\begin{tabular}{|l|l|l|l|l|}
\hline \multirow{2}{*}{ Point } & \multirow{4}{*}{ Resp. } & \multicolumn{2}{|l|}{ Kelas X } & \multirow{2}{*}{$\begin{array}{l}\text { Pelisih } \\
(\%)\end{array}$} \\
\cline { 3 - 4 } & & $\sqrt{\%}$ & $\mathbf{X}$ & \\
\hline A & 14 & $87,7 \%$ & $12,3 \%$ & $75,4 \%$ \\
\hline B & 14 & $30,1 \%$ & $69,9 \%$ & $39,8 \%$ \\
\hline \multicolumn{2}{|l|}{ Jumlah } & $127,8 \%$ & $82,2 \%$ & 115,2 \\
\hline
\end{tabular}

Sebanyak $12,3 \%$ belum memiliki banyak perbendaharaan kosakata bahasa Indonesia. Selanjutnya sebanyak 30,1\% merasa tidak perlu belajar bahasa Indonesia. Berdasarkan hasil angket dapat diidentifikasi bahwa kesulitan yang dihadapi oleh diri santri kemungkinan disebabkan karena masih kurangnya motivasi dari diri santri atau pun dari orangtua dan guru, sehingga santri dalam belajar bahasa Indonesia masih kurang tekun. Hal tersebut tentu berpengaruh terhadap penguasaan berbahasanya.
2) Aspek Sarana/prasarana

Tabel 6.2: Data Konversi Angket Aspek Sarana/prasarana

\begin{tabular}{|l|l|l|l|l|}
\hline \multirow{2}{*}{ Point } & \multirow{2}{*}{ Resp. } & \multicolumn{2}{|l|}{ Kelas X } & \multirow{2}{*}{\begin{tabular}{l} 
Pelisih \\
\cline { 3 - 4 }
\end{tabular}} \\
\cline { 3 - 4 } & & $\sqrt{\%})$ \\
\hline A & 14 & $33,3 \%$ & $66,7 \%$ & 33,4 \\
\hline \multicolumn{2}{|l|}{ Jumlah } & $33,3 \%$ & $66,7 \%$ & 33,4 \\
\hline
\end{tabular}

Sebanyak $66,7 \%$ belum memiliki Kamus Besar Bahasa Indonesia.

Berdasarkan hasil angket dapat diidentifikasi bahwa kesulitan yang dihadapi oleh santri disebabkan karena masih kurangnya fasilitas yang disediakan oleh ponpes sebagai upaya peningkatan penguasaan berbahasa santri. Kekurangan tersebut meliputi pengadaan buku di perpustakaan, ruang baca perpustakaan yang kurang lega.

\section{3) Aspek Keterbatasan Jam Belajar}

Tabel 6.3: Data Konversi Angket Aspek Keterbatasan Jam Belajar

\begin{tabular}{|l|l|l|l|l|}
\hline \multirow{2}{*}{ Point } & \multirow{2}{*}{ Resp. } & \multicolumn{2}{l|}{ Kelas X } & \multicolumn{2}{l}{$\begin{array}{l}\text { Selisih } \\
(\%)\end{array}$} \\
\cline { 3 - 4 } & & \multicolumn{2}{|l|}{ Persentase } & \\
\cline { 3 - 4 } & $\sqrt{ }$ & $\mathbf{X}$ & \\
\hline A & 14 & $32,9 \%$ & $67,1 \%$ & $35,8 \%$ \\
\hline \multicolumn{2}{|l|}{ Jumlah } & $32,9 \%$ & $67,1 \%$ & $35,8 \%$ \\
\hline
\end{tabular}

Sebanyak $67,1 \%$ belum merasa 4 jam pelajaran masih belum paham dengan materi pelajaran yang disampaikan. Berdasarkan hasil angket dapat diidentifikasi bahwa kesulitan yang dihadapi oleh diri santri disebabkan karena masih sulit memahami materi yang disampaikan oleh guru hanya dengan 4 jam pelajaran, serta waktu belajar santri di luar sekolah yang masih kurang dimanfaatkan sebagian besar santri. 
Nanang Rahmat Hidayat, Santhy Hawanti

Problematika Penguasaan Tiga Bahasa pada Santri Putra Kelas X di Pondok Pesantren Modern Zam-Zam Muhammadiyah Cilongok Tahun Ajaran 2019/2020

4) Aspek Guru dan Metode Pembelajaran

Tabel 6.4: Data Konversi Angket Aspek Guru dan Metode Pembelajaran

\begin{tabular}{|l|l|l|l|l|}
\hline \multirow{2}{*}{ Point } & \multirow{2}{*}{ Resp. } & \multicolumn{2}{|l|}{ Kelas X } & \multirow{2}{*}{$\begin{array}{l}\text { Selisih } \\
(\%)\end{array}$} \\
\cline { 3 - 4 } & & \multicolumn{2}{|l|}{ Persentase } & \multirow{2}{*}{} \\
\cline { 3 - 5 } & & $\sqrt{ }$ & $\mathbf{X}$ & \\
\hline A & 14 & $97,3 \%$ & $2,7 \%$ & $94,6 \%$ \\
\hline B & 14 & $32,9 \%$ & $67,1 \%$ & $34,2 \%$ \\
\hline \multicolumn{2}{|l|}{ Jumlah } & $130,2 \%$ & $69,8 \%$ & $128,8 \%$ \\
\hline
\end{tabular}

Sebanyak 2,7\% tidak mudah memahami materi yang disampaikan guru bahasa Indonesia. Selanjutnya sebanyak 32,9\% lebih suka membaca materi saja daripada praktek berbicara. Berdasarkan hasil angket dapat diidentifikasi bahwa kesulitan yang dihadapi oleh diri siswa kemungkinan disebabkan karena masih sulitnya siswa memahami penjelasan guru dan belum tingginya motivasi siswa dalam melakukan praktik berbicara di kelas sehingga kemampuan berbicaranya belum berkembangn baik.

5) Aspek Lingkungan/social

Tabel 6.5: Data Konversi Angket Aspek lingkungan/social

\begin{tabular}{|c|c|c|c|c|}
\hline \multirow{3}{*}{ Point } & \multirow{3}{*}{ Resp. } & \multicolumn{2}{|c|}{ Kelas X } & $\begin{array}{l}\text { Selisih } \\
(\%)\end{array}$ \\
\hline & & \multicolumn{2}{|c|}{ Persentase } & \\
\hline & & $\sqrt{ }$ & $\mathbf{X}$ & \\
\hline A & 14 & $\begin{array}{r}90,4 \\
\%\end{array}$ & $9,6 \%$ & $80,8 \%$ \\
\hline B & 14 & $60,3 \%$ & $39,7 \%$ & $20,6 \%$ \\
\hline $\mathrm{C}$ & 14 & $97,3 \%$ & $2,7 \%$ & $94,6 \%$ \\
\hline \multicolumn{2}{|c|}{ Jumlah } & $248 \%$ & 52 & $196 \%$ \\
\hline
\end{tabular}

Sebanyak 9,6\% belum mengetahui situasi penggunaan bahasa resmi dan tidak resmi. Selanjutnya sebanyak $39,7 \%$ mengaku lebih senang menggunakan bahasa asing/daerah daripada menggunakan bahasa Indonesia. Sedangkan 97,3\% sering menyapa/ bercakap menggunakan bahasa Indonesia ketika bertemu guru atau teman di sekolah. Berdasarkan hasil angket dapat diidentifikasi bahwa kesulitan yang dihadapi oleh santri kemungkinan disebabkan karena ketidaktahuan santri dalam membedakan penggunaan bahasa pada situasi tertentu.

\section{KESIMPULAN}

Berdasarkan hasil da pembahasan maka dapat disimpulkan bahwa santri lebih banyak mengalami problema $\neg$ tika pada aspek 1) aspek fonologi, (2) aspek morfologi, (3) aspek sintaksis, (4) aspek semantik, (5) aspek kemampuan individu siswa, (6) aspek keterbatasan jam belajar, dan (6) aspek guru dan metode pembelajaran.

\section{DAFTAR PUSTAKA}

Chaer, Abdul. (2007). Linguistik Umum. Jakarta: PT Rineka Cipta.

Iskandarwassid,. dkk. (2011). Strategi Pembelajaran Bahasa. Bandung: PT Remaja Rosdakarya Offset.

Izaan, Ahmad. (2016). Metodologi Pembelajaran Bahasa Inggris. Bandung: Humaniora.

Kompei. (2018). Manajeman dan Kepemimpinan Pondok Pesantern. Jakarta: Prenadamedia Group.

Chirzin, M Habib,. dkk. (2017). Standar Pendidikan Pesantern Muhammadiyah Tahun 2017. LP2M

Pateda, Mansoer. (1990). Aspek-aspek Psikolinguistik. Yogyakarta: Kanisius.

Rohman, Fathur. (2015). Metodologi Pembelajaran Bahasa Arab. Malang: Madani.

Sugiyono. (2011). Metode Penelitian Kuantitatif, Kualitatif, dan $R \& D$. Bandung: Alfabeta.

WS, Winkel. (1983). Psikologi Pendidikan dan Evaluasi Belajar. Jakarta: Gramedia. 